(RESEARCH ARTICLE)

\title{
Parasitism of Loranthaceae on crops: case of plantations in rural area on the periphery of Jean Lorougnon Guédé University of Daloa, Central-West Côte d'Ivoire
}

\author{
Denis-Esdras Anoh Amon *, Victoire Annick Koulibaly and El Amine Hamed Sako \\ Agroforestry Training and Research Unit, Jean Lorougnon Guédé University. PO Box, 150 Daloa, Côte d'Ivoire.
}

Publication history: Received on 07 August 2020; revised on 16 August 2020; accepted on 18 August 2020

Article DOI: https://doi.org/10.30574/wjarr.2020.7.2.0293

\begin{abstract}
In Côte d'Ivoire, tree crops are an important source of agricultural income. Unfortunately, the disquieting expansion of Loranthaceae is observed on many annuity crops like cocoa trees, coffee trees and rubber trees. This situation can harm the economy generated by the activity out coming from these speculations. The aim of this study is therefore, to know the diversity of Loranthaceae and to determine the extent of their infestation on crops, in rural area on the periphery of the University Jean Lorougnon Guédé. The inventories were carried out by surface and roving survey methods coupled with direct observations on individuals of cocoa trees, coffee trees and rubber trees. In total, 3 species of Loranthaceae: Globimetula danglagei, Phragmanthera capitata var. capitata and Tapinanthus bangwensis (T. bangwensis) were inventoried in the plantations. T. bangwensis is the most abundant parasite on crops. Forty-one host species divided into 34 genera and 21 families have been identified within the plantations. The Fabaceae (19.51\%) and the Malvaceae $(9.75 \%)$ are the most infested families. On cocoa trees, coffee trees and rubber trees, the parasitism of Loranthaceae respectively indicated the following pairs of values (incidence and severity index): (42.86 $\pm 7.02 \%$ and $33.99 \pm 7.10 \%)$, $(25.93 \pm 11.65 \%$ and $21.92 \pm 3.11 \%)$ and $(6.38 \pm 0.97 \%$ and $6.72 \pm 1.55 \%)$. The results indicated a significant difference between the incidences of infestation, the crop severity index as a function of Diameter Breast Height (DBH). The incidence of Loranthaceae infestation on all the annuity crops is around $24.93 \pm 17.20 \%$ and the severity index is $20.88 \pm 12.47 \%$.
\end{abstract}

Keywords: Annuity crops; Loranthaceae, Incidence; Severity index; Côte d'Ivoire; West Africa

\section{Introduction}

In Africa, more than $80 \%$ of countries have their development based on agriculture [1]. The Côte d'Ivoire in particular owes its agricultural dynamism to annuity crops such as cocoa trees, coffee trees and rubber trees which constitute an important source of income for many growers [2]. In fact, cocoa cultivation alone provides a livelihood for more than 4 million people and generates for the country nearly 450 billion XOF per year [3].

Unfortunately, these crops are subjected over the years to stress like the ageing of the orchards and the drastic drop in the prices of products on the international marched [4]. Today, there is also the debasement of orchards due to attacks by vascular hemiparasitic chlorophyll plants of the Loranthaceae family [5]. These hemiparasitic plants live and develop high on the branches of many cultivated and spontaneous plants, which they affect to inconstant grades [6] and [7]. These parasitic plants, once implanted on the host, develop a system called a sucker or endophytic apparatus that penetrates the tissues of the parasite. By this mode of infestation, they take away for their profit, the water and mineral substances necessary for their own development [8].

In Côte d'Ivoire, several tree crops, in particular cocoa, coffee and rubber trees, have become, year after year, privileged hosts of these parasitic plants [9]. They affect by their parasitism, the growth, reduce the yield and often case the death

\footnotetext{
${ }^{*}$ Corresponding author: Amon Anoh Denis-Esdras

Agroforestry Training and Research Unit, Jean Lorougnon Guédé University. PO Box, 150 Daloa, Côte d'Ivoire. 
of the parasitized subject [10]. Thus, the Loranthaceae represent a major flail against which a fight is necessary, given the extent of the damage caused to the branches of their hosts. According to Wood [11], any effective control to be carried out against these hemiparasitic plants requires as a prelude knowing the manifestation of their infestation on their different hosts.

The rural area on the periphery of the Jean Lorougnon Guédé University destined for the subsequent construction of university infrastructure, contain plantations of annuity crops infested with Loranthaceae [12]. It therefore seems important to carry out a qualitative inventory of the species of this family and to determine the incidence and severity of their infestation on the crops and their hosts before their destruction.

\section{Material and methods}

\subsection{Study area}

The study was carried out in the Jean Lorougnon Guédé University, site of the study (fig. 1) with geographical coordinates $6^{\circ} 27^{\prime} 00^{\prime \prime}$ north latitude and $5^{\circ} 56^{\prime} 00^{\prime \prime}$ west longitude is located $141 \mathrm{~km}$ from Yamoussoukro. It is defend the Jean Lorougnon Guédé University, site of the study. The climate of the study area is equatorial with two rainy seasons and two dry seasons. The annual precipitation change from $1.300 \mathrm{~mm}$ between the driest and $1.800 \mathrm{~mm}$ in the wettest month. The vegetation belongs to the mesophilic sector of the Guinean domain [13], today made up of forest islet and savannahs.

\subsection{Material}

The biological material included the parasitic Loranthaceae and woody species found in plantations. The technical equipment consists of a geographic positioning device (GPS), a digital camera, a pair of binoculars, a tape measure, survey plugs, pruning shears and twine.

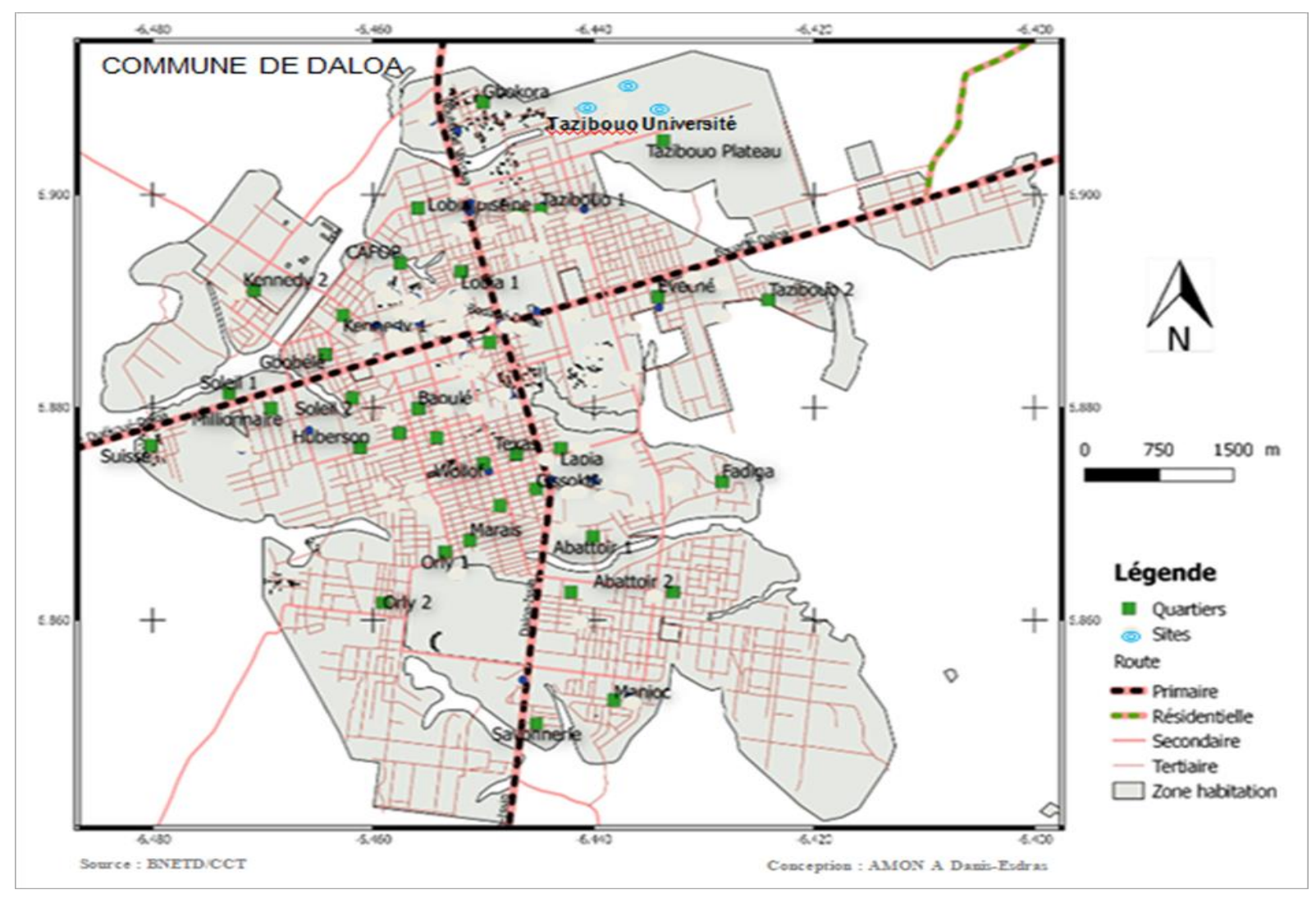

Figure 1 Presentation of the area and study 


\subsection{Methods}

For the study, the method of surface surveys which consists in listing the individuals encountered on square or rectangular areas [14], associated with direct observations on individuals of cocoa trees, coffee trees and rubber trees to note the presence or absence of the parasite were adopted. The inventory consisted of counting from three survey plots of $60 \mathrm{~m} \times 40 \mathrm{~m}\left(2400 \mathrm{~m}^{2}\right)$ delimited in each plantation of cocoa trees, coffee trees and rubber trees. For a more careful inventory of non-parasitized individuals and those parasitized as well as the enumeration of Loranthaceae tufts,

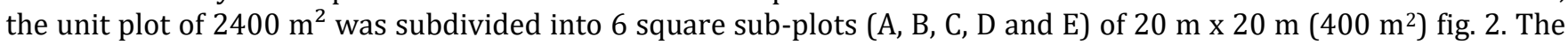
Diameter Breast Height (DBH) at $1.30 \mathrm{~m}$ from the floor) of all cultivated plant species, spontaneous parasitized and those non-parasitized encountered in these sub-plots was noted. Also, between two plots of $2400 \mathrm{~m}^{2}$, itinerant surveys were carried out for more exhaustive data. It consisted of passing through the plantations in all directions to identify all the plants of crops and other woody parasitized and those not parasitized.

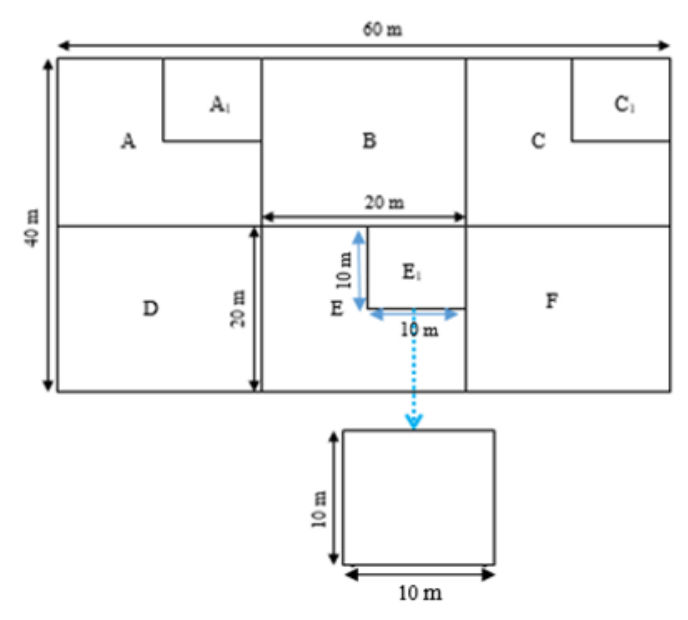

Figure 2 Reading device

In these subplots, the Loranthaceae species encountered have been the target of direct observations. It consisted in observing the parasites on the crops and spontaneous species encountered in order to count their number of tufts on the parasitized individuals. The data collected made it possible to determine:

- the incidence of infestation of Loranthaceae on the types of crops and the plant species parasitized according to the formula used by Mohamed et al. [15]:

$$
\text { Incidence of infestation }(\%)=\frac{\text { Number of plants infested with Loranthaceae }}{\text { Total number of plants inventoried in the plantation }} \times 100
$$

- the parasitic sensitivity of each host plant. It was assessed on a predefined scale according to the number of parasitic species per host: not very sensitive ( 1 to 2 parasites), sensitive ( 3 to 4 parasites), highly sensitive (5 and more).

- the parasite specificity rate (Psr) of Loranthaceae Houenon et al. [16]:

$$
P s r=\frac{\text { Number of hosts a parasitic species }}{\text { Total number of hosts }} \times 100
$$


This rate is expressed as a percentage. The low value of Tsp reveals that the parasitic species infests many host individuals and the high value reflects a small number of individuals infested with the parasitic species. Parasite classes were determined: very high parasite specificity: [0 to $2 \%]$, average parasite specificity: ]2 to $6 \%$ ] and low parasite specificity: > 8\%.

To assess the severity of infestation of crops by Loranthaceae, 15 crop plants were randomly selected from 3 subplots $\left(A_{1}, C_{1}\right.$ and $\left.E_{1}\right)$ of $100 \mathrm{~m}^{2}$ each (fig. 2). A total, 45 plants per plantation of cocoa, coffee and rubber trees were selected. An infestation severity index was established on a scale of 0 to 4 depending on the number of tufts or fixation point of Loranthaceae species (s) per affected individual (Table 1).

Table 1 Loranthaceae infection severity index scale on crops

\begin{tabular}{lll}
\hline Severity index of attacks & Note & Number of tufts/plants \\
\hline No infestation & 0 & 0 \\
Light infestation & 1 & 1 to 3 tufts by plant \\
Moderate infestation & 2 & 4 to 6 tufts by plant \\
Severe infestation & 3 & 7 to 9 tufts by plant \\
Very serious & 4 & $>9$ tufts by plant \\
\hline
\end{tabular}

The severity indices $(S I)$ of infestation of Loranthaceae on crop types were calculated using the following formula [17]:

$$
S I=\left[\frac{(0 \times a)+(1 \times b)+(2 \times c)+(3 \times d)+(4 \times e)}{a+b+c+d+e}\right] \times \frac{100}{4}
$$

whith a, b, c, d and e are the number of trees falling into the crescent infection categories 0 to 4.

The identification of the spontaneous plant crops and species hosts of Loranthaceae has been made using works such as Aké-Assi [18] and Biodiversity of West Africa Forest Bongers et al. [19]. The determination of Loranthaceae species was made using the work of Ballé et Halle [20], Boussim [8], Amon [9], Soro [21] and by the comparison of the Herbarium Flora of the National Floristic Center (CNF).

\subsection{Statistical processing}

The data generated was subjected to one-way analysis of variance (ANOVA) to compare the mean values of incidence and severity of infestation on crops and plant species identified in the plantations. This program provides, in the event of significant differences, for a comparison of the means [22], using Duncan's test at the $5 \%$ level $(\alpha<0.05)$.

\section{Results}

\subsection{Loranthaceae species encountered}

Three (3) species of Loranthaceae were inventoried on crops, trees and shrubs of plantations in rural areas of the periphery of the University Jean Lorougnon Guédé, in the Central-West of Côte d'Ivoire. They are: Globimetula-dinklagei subsp. assiana Engl. (fig. 3), Phragmanthera capitata var. capitata (Spreng) Ballé (fig. 4) and Tapinanthus bangwensis (Engl. and K. Krause) Danser (fig. 5) each belonging to a separate genus. 


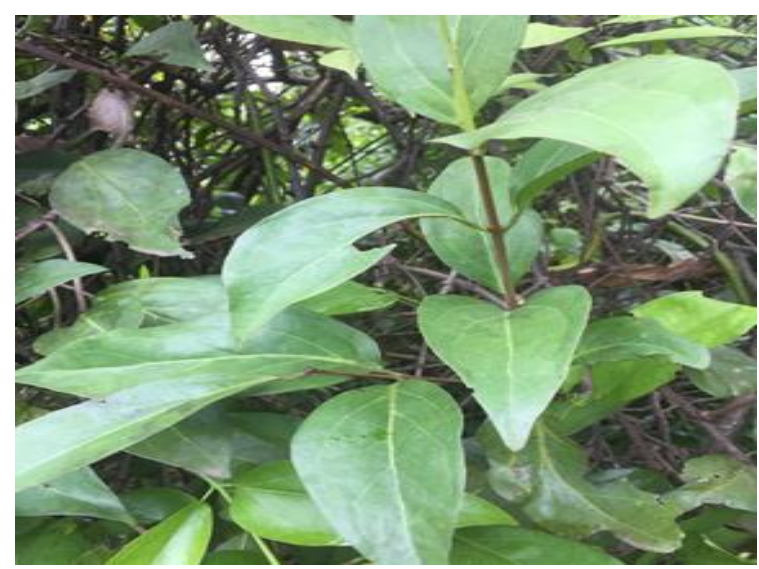

Figure 3 Leafy twigs of $G$. dinklagei

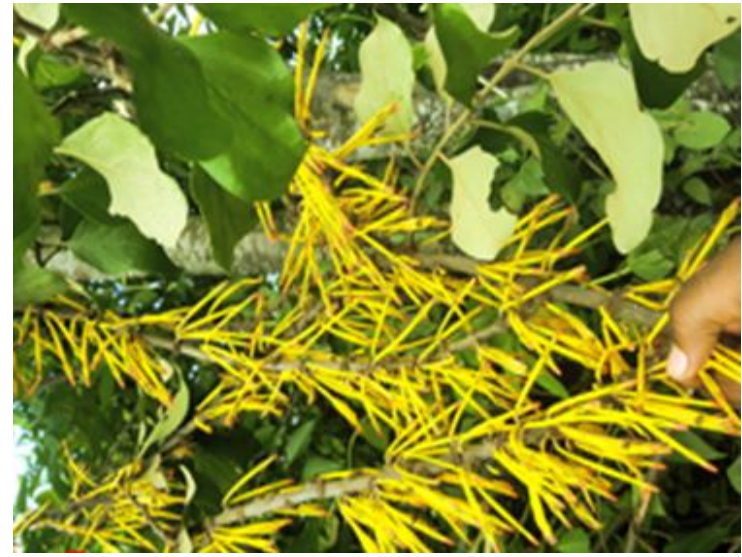

Figure 4 Inflorescences a of $P$. capitata var. capitata

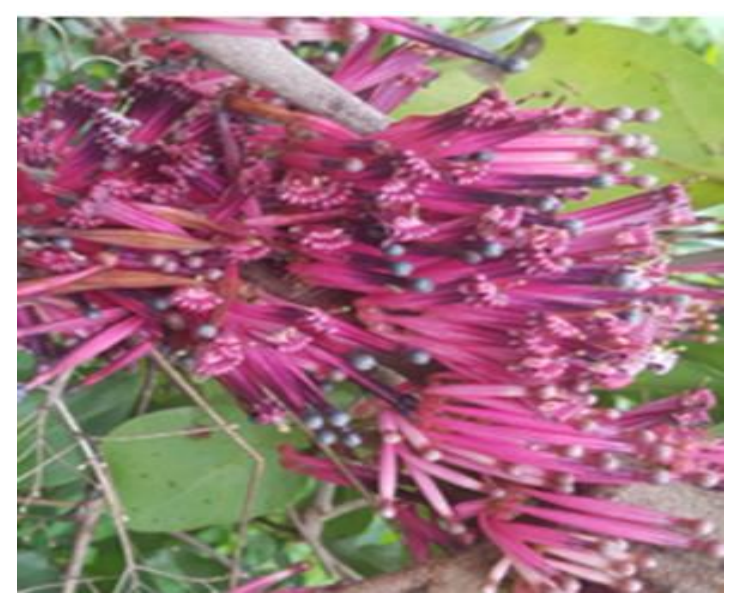

Figure 5 Inflorescences of T. bangwensis

\subsection{Parasite specificity rate of parasitic species}

The levels of parasite specificity of the Loranthaceae species determined oscillate between $4.87 \%$ and $95.10 \%$ (Table 2). G. dinklagei has an average parasite specificity of around $4.87 \%$. On the other hand, P. capitata var. capitata (60.97\%) and T. bangwensis $(95.10 \%)$ both show low parasitic specificity in the annuity crops in rural areas of the periphery of the University Jean Lorougnon Guédé.

Table 2 Loranthaceae species found on hosts in plantations $(n=41)$

\begin{tabular}{lll}
\hline Species & Number of hosts parasitized & Spfte prste (\%) \\
\hline $\begin{array}{ll}\text { Globimetula dinklagei subsp. assiana Engl. } \\
\begin{array}{l}\text { Phragmantera capitata var. capitata } \\
\text { (Spreng.) Ballé }\end{array}\end{array}$ & 4.87 \\
T. bangwensis (Engl. et K. Krause) Danser & 25 & 60.97 \\
\hline
\end{tabular}

Meaning of abreviations : Spfte - Specificity ; prste - parasite ; $\mathrm{Nb}$ - Number

\subsection{Distribution of Loranthaceae on crops}

The 3 species of Loranthaceae inventoried, namely G. dinklagei subsp. assiana Engl., P. capitata var. capitata and T. bangwensis are parasites on cocoa trees (fig. 6). Among these species, P. capitata var. capitata and T. bangwensis parasitize coffee and rubber trees with a predominance of $P$. capitata var. capitata on the rubber trees in rural areas of the periphery of the University. T. bangwensis with 517 tufts registered on cocoa trees and 83 tufts on coffee trees for a total of 600 tufts, or $73.71 \%$ of the tufts appears as the abundant species on these two crops. In contrast, P. capitata var. 
capitata is predominant on rubber trees with 79 tufts (86.8\%). Overall, T. bangwensis is the most abundant parasite on crops in the study area.

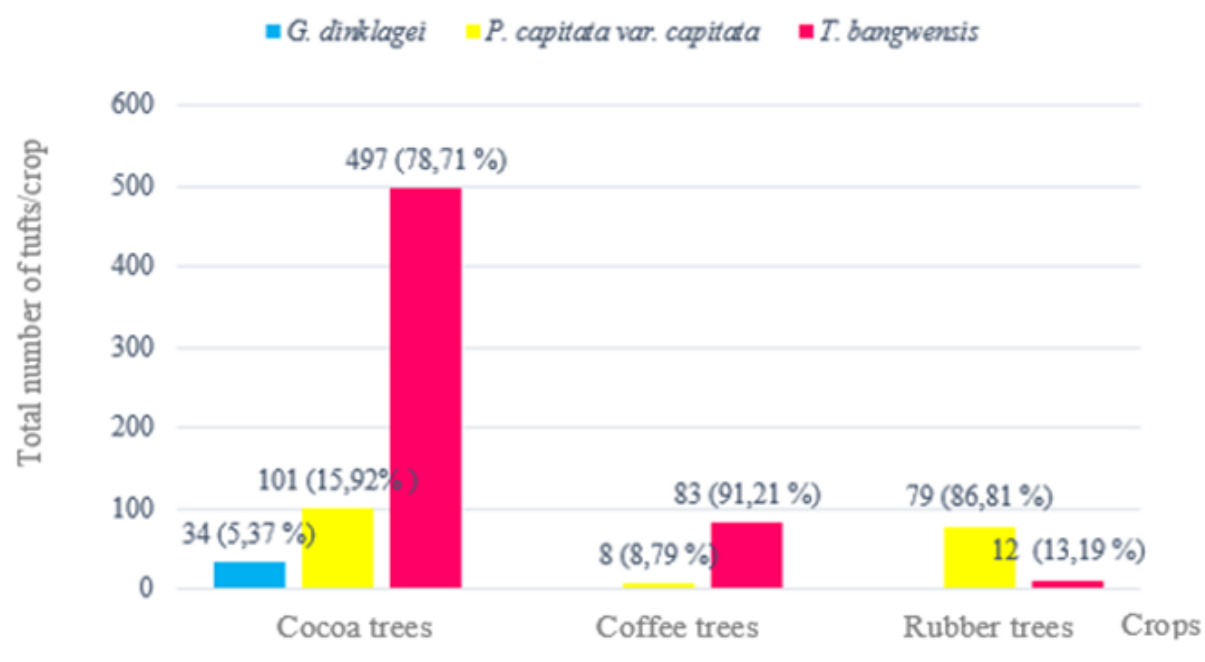

Figure 6 Distribution of Loranthaceae species according to crops

\subsection{Diversity of inventoried host species}

Forty-one host species divided into 34 genera and 21 families were inventoried in the plantations in rural areas of the periphery of the University Jean Lorougnon Guédé (Table 3). The Fabaceae are the most diverse family with 8 parasitized species, or 19.51\%. Then come the Malvaceae with 4 species (9.75\%), followed by Apocynaceae, Euphorbiacae, Moraceae and Rutaceae with each 3 taxa (7.31\%). Among these families, one of them has 2 species (4.87\%) and 13 with 1 species each (2.43\%). These 41 host species total $46.32 \%$ of spontaneous species and $53.65 \%$ of associated species. In terms of number of hosts, the coffee trees contain a majority of $68.29 \%$ of parasitized woody plants within them (Table 3). Next come cocoa trees with 58.53\% of taxa infested with Loranthaceae within it and rubber trees (9.75\%). Of these host taxa, Albizia is the most attacked genus (5 individuals, or $14.70 \%)$. It is followed by Citrus with 3 taxa (8.82\%) and Ficus (2 taxa), or 5.88\%. Fourteen other parasitized genera have a separate taxon (2.94\%). We cite among others: Annona, Adansonia, Alstonia, Bombax, Ceiba, Cnestis, Cola, Morinda, Newbouldia, Persea and Vitellaria.

\subsection{Parasitic sensitivity of host plants by the Loranthaceae encountered}

Of the 41 inventoried host species, 20 (either 48.78\%) are sensitive to attacks by Loranthaceae with the presence of two to three parasitic species against 21 taxa (either $51.22 \%$ ) not very sensitive to parasites infested by a single parasitic species. $G$. dinklagei is the parasite with moderate parasite specificity (4.87\%). On the other hand, $P$. capitata var. capitata $(60.97 \%)$ and T. bangwensis $(95.10 \%)$ both show low parasite specificity in major crops (Table 3).

\subsection{Incidence and severity of infestation of Loranthaceae on host species}

The incidence values of host species infestation vary between 18.75 and $100 \%$ (Table 3). The maximum $100 \%$ incidence values are obtained for 6 associated species (Albizia lebbeck, Citrus limon, Delonix regia, Parkia biglobosa, Terminalia catappa and Vitellaria paradoxa) and 7 spontaneous species (Tabernaemontana crassa, Bombax buenopozense, Ceiba pentandra, Ficus sur, Blighia sapida, Harrisonia abyssinica and Sterculia tragacantha). Among the 41 host plants, 10 species, or $24.39 \%$, recorded incidence values greater than or equal to $50 \%$. We cite: Cola nitida (80\%), Annona muricata (75\%), Newbouldia laevis (66.67\%), A. adianthifolia (62.50\%), Persea americana (54.55\%) and Cnestis ferruginea, Diospyros mannii, Bridelia grandis, Mallotus oppositifolius and Margaritaria discoidea with an incidence value of $50 \%$ each (Table 3).

Regarding the indices of severity of infestation of Loranthaceae on the host species evaluated, they change from 1.50 to $32 \%$ (Table 3). P. americana (13.83\%), Spondias mombin (13\%), A. glaberrima (12.20\%), A. adianthifolia (12\%), N. laevis (11.25\%), Cola nitida (11\%) and V. paradoxa (11\%) are the most infested species with high severity index values. They are followed by Morinda morindoides (8.50\%), Psidium guajava (6.89\%), A. zygia (6\%), A. ferruginea (5.7\%), A. lebbeck (5\%) and A. muricata (5\%). The values of the lowest severity indices are recorded on Coffea canephora (2.25\%), Citrus 
sinensis $(2.15 \%)$ and D. regia (2\%). Among the host plant cohort, Theobroma cacao and C. canephora recorded high infestation severity indices of $33.11 \%$ and $25.81 \%$, respectively (Table 3). Six spontaneous species (or 14.19\%) recorded high severity indices, namely: C. pentandra (32\%), B. buenopozense (29\%), H. abyssinica (10.50\%), Baphia nitida (8\%), D. mannii (7\%) and Blighia sapida (6\%).

Table 3 Prevalence of Loranthaceae on the host species identified in crops

\begin{tabular}{|c|c|c|c|c|c|c|}
\hline \multirow{2}{*}{ Species \& Families } & \multicolumn{3}{|c|}{$\begin{array}{l}\text { Parasites } \\
\text { species }\end{array}$} & \multirow[t]{2}{*}{ Ptsp } & \multirow{2}{*}{$\begin{array}{l}\text { Incidence of } \\
\text { infestation (\%) }\end{array}$} & \multirow{2}{*}{$\begin{array}{l}\text { Indix of } \\
\text { Severity (\%) }\end{array}$} \\
\hline & $G d$ & $P c$ & $T b$ & & & \\
\hline \multicolumn{7}{|l|}{ Anacardiaceae } \\
\hline Spondias mombin Linn. & + & + & + & $\mathrm{s}$ & 33.33 & 13 \\
\hline \multicolumn{7}{|l|}{ Annonaceae } \\
\hline Annona muricata Linn. & - & + & + & $\mathrm{s}$ & 75 & 5 \\
\hline \multicolumn{7}{|l|}{ Apocynaceae } \\
\hline Alstonia boonei De Wild. & - & + & + & $\mathrm{s}$ & 8.75 & 5.67 \\
\hline $\begin{array}{l}\text { Holarrhena floribunda var. } \\
\text { floribunda (G. Don) Dur. \& Schinz }\end{array}$ & - & + & + & s & 33.33 & 4.20 \\
\hline Tabernaemontana crassa Benth. & - & - & + & ps & 100 & 3 \\
\hline \multicolumn{7}{|l|}{ Bignoniaceae } \\
\hline $\begin{array}{l}\text { Newbouldia laevis (P. Beauv.) } \\
\text { Seemann ex Bureau }\end{array}$ & - & + & + & $\mathrm{s}$ & 66.67 & 11.25 \\
\hline \multicolumn{7}{|l|}{ Bombacaceae } \\
\hline Adansonia digitata Linn. & - & + & - & ps & 33.33 & 3 \\
\hline \multicolumn{7}{|l|}{ Caesalpiniaceae } \\
\hline Delonix regia Raf. & - & - & + & ps & 100 & 2 \\
\hline \multicolumn{7}{|l|}{ Combretaceae } \\
\hline Terminalia catappa Linn. & - & - & + & ps & 100 & 3 \\
\hline \multicolumn{7}{|l|}{ Connaraceae } \\
\hline Cnestis ferruginea DC. & - & - & + & ps & 50 & 6 \\
\hline \multicolumn{7}{|l|}{ Ebenaceae } \\
\hline Diospyros mannii Hiern. & - & - & + & ps & 50 & 7 \\
\hline \multicolumn{7}{|l|}{ Euphorbiaceae } \\
\hline Bridelia grandis Pierre ex Hutch. & - & - & + & ps & 50 & 5 \\
\hline Jatropha curcas Linn. & - & - & + & ps & 33.33 & 3 \\
\hline $\begin{array}{l}\text { Mallotus oppositifolius (Geisel.) } \\
\text { Müll. Arg. }\end{array}$ & - & - & + & ps & 50 & 2 \\
\hline $\begin{array}{l}\text { Margaritaria discoidea (Baill.) } \\
\text { Webster }\end{array}$ & - & - & + & ps & 50 & 1.50 \\
\hline \multicolumn{7}{|l|}{ Fabaceae } \\
\hline Baphia nitida Lodd. & - & - & + & ps & 25 & 8 \\
\hline Acacia ataxacantha DC. & - & + & + & ps & 22.22 & 2 \\
\hline $\begin{array}{l}\text { Albizia glaberrima (Schum. \& } \\
\text { Thonn.) Benth. }\end{array}$ & - & + & + & $\mathrm{s}$ & 38.46 & 12.20 \\
\hline
\end{tabular}




\begin{tabular}{|c|c|c|c|c|c|c|}
\hline $\begin{array}{l}\text { Albizia adianthifolia (Schumach.) } \\
\text { W.F. Wright }\end{array}$ & - & + & + & s & 62.50 & 12 \\
\hline $\begin{array}{l}\text { Albizia ferruginea (Guill. \& Perr.) } \\
\text { Benth. }\end{array}$ & - & + & + & $\mathrm{s}$ & 37.50 & 5.67 \\
\hline Albizia lebbeck (Linn.) Benth. & - & - & + & ps & 100 & 5 \\
\hline Albizia zygia (DC.) J.F. Macbr. & - & + & + & s & 37.50 & 6 \\
\hline Parkia biglobosa (Jacq.) Benth. & - & - & + & ps & 100 & 3 \\
\hline \multicolumn{7}{|l|}{ Lauraceae } \\
\hline Persea americana Mill. & - & + & + & s & 54.55 & 13.83 \\
\hline \multicolumn{7}{|l|}{ Malvaceae } \\
\hline Bombax buenopozense P. Beauv. & - & + & + & s & 100 & 29 \\
\hline Ceiba pentandra (Linn.) Gaerth. & - & + & + & $\mathrm{s}$ & 100 & 32 \\
\hline $\begin{array}{l}\text { Cola nitida (Vent.) Schott } \\
\text { \& Endl. }\end{array}$ & - & + & + & $\mathrm{s}$ & 80 & 11 \\
\hline Theobroma cacao Linn. & + & + & + & $\mathrm{s}$ & 33.11 & 2.58 \\
\hline \multicolumn{7}{|l|}{ Moraceae } \\
\hline $\begin{array}{l}\text { Antiaris toxicaria var. africana } \\
\text { (Engl.) C.C. Berg }\end{array}$ & - & - & + & ps & 18.18 & 4 \\
\hline Ficus exasperata Vahl & - & - & + & ps & 33.33 & 3 \\
\hline Ficus sur Forsk. & - & + & - & ps & 100 & 2 \\
\hline \multicolumn{7}{|l|}{ Myrtaceae } \\
\hline Psidium guajava Linn. & - & + & + & $\mathrm{s}$ & 30 & 6.89 \\
\hline \multicolumn{7}{|l|}{ Rubiaceae } \\
\hline Coffea canephora A. Froehner & - & + & + & $\mathrm{s}$ & 25.81 & 2.25 \\
\hline $\begin{array}{l}\text { Morinda morindoides (Baker) } \\
\text { Milne-Redh. }\end{array}$ & - & + & + & $\mathrm{s}$ & 25 & 8.50 \\
\hline \multicolumn{7}{|l|}{ Rutaceae } \\
\hline Citrus limon Burn. f. & - & - & + & ps & 100 & 3 \\
\hline Citrus reticulata Blanco & - & - & + & ps & 10.81 & 3.75 \\
\hline Citrus sinensis (L.) Osbeck & - & + & + & ps & 40.63 & 2.15 \\
\hline \multicolumn{7}{|l|}{ Sapindaceae } \\
\hline Blighia sapinda K. D. Koenig & - & + & + & $\mathrm{s}$ & 100 & 6 \\
\hline \multicolumn{7}{|l|}{ Sapotaceae } \\
\hline Vitellaria paradoxa C. F. Gaertn. & - & + & + & $\mathrm{s}$ & 100 & 11 \\
\hline \multicolumn{7}{|l|}{ Simaroubaceae } \\
\hline Harrisonia abyssinica Oliv. & - & + & + & $\mathrm{s}$ & 100 & 10.5 \\
\hline \multicolumn{7}{|l|}{ Sterculiaceae } \\
\hline Sterculia tragacantha Lindl. & - & - & + & ps & 100 & 2 \\
\hline Total & 2 & 25 & 39 & & 35.23 & 5.46 \\
\hline
\end{tabular}


M. discoidea (1.50\%), Acacia ataxacantha, Ficus sur and Sterculia tragacantha are the least infested host species, each with an infestation severity index of $2 \%$.

The incidence of infestation of host species by Loranthaceae in all crops in rural areas of the periphery of the Jean Lorougnon Guédé is around $35.25 \%$ and the severity index is 5.46\% (Table 3).

\subsection{Incidence and severity of Loranthaceae infestation on crops}

The values of the incidence of Loranthaceae infestation on crops in rural areas of the periphery of the Jean Lorougnon Guédé University evaluated change from $6.38 \pm 0.97$ to $42.86 \pm 7.02 \%$ (fig. 7). Cocoa trees are the most parasitized crops with an infestation incidence of around $42.86 \pm 7.02 \%$. Then come rubber trees $(25.93 \pm 11.65 \%)$. Coffee trees are the least parasitized $(6.38 \pm 0.97 \%)$. The analysis of variance carried out effectively indicates three static groups a, $\mathrm{b}$ and $\mathrm{c}$ $(\mathrm{P}=0.003)$ between the incidences of infestation of Loranthaceae recorded on the crops (fig. 7). The incidence of Loranthaceae infestation on crops in rural areas of the periphery of the Jean Lorougnon Guédé University taken together is $24.93 \pm 17.20 \%$.

Regarding the severity index of infestation of Loranthaceae on crops, the values range from $6.72 \pm 1.55$ to $33.99 \pm 7.10 \%$ (fig. 8). Cocoa trees are the most infested with a severity index of around $33.99 \pm 7.10 \%$. Then come rubber trees with an infestation severity of $21.92 \pm 3.11 \%$. Coffee trees are the least infested $(6.72 \pm 1.55 \%)$. The analysis of variance carried out effectively indicates 3 statistical groups $a, b$ and $c(P=0.001)$ fig. 8 . The severity of infestation of Loranthaceae on types of crops in rural areas of the periphery of the University Jean Lorougnon Guédé taken together is $20.88 \pm 12.47 \%$.

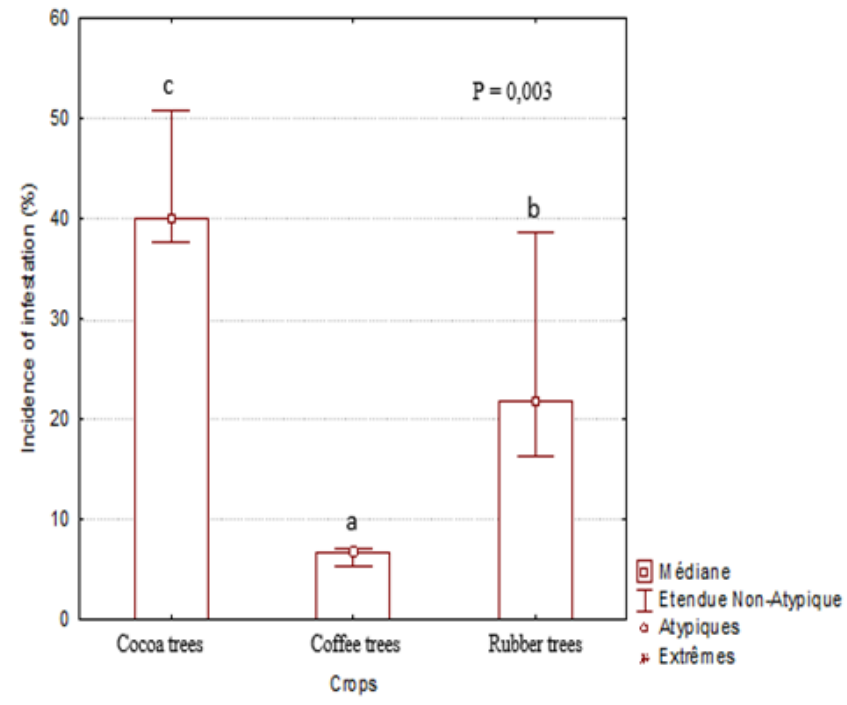

Figure 7 Incidence of infestation on crops

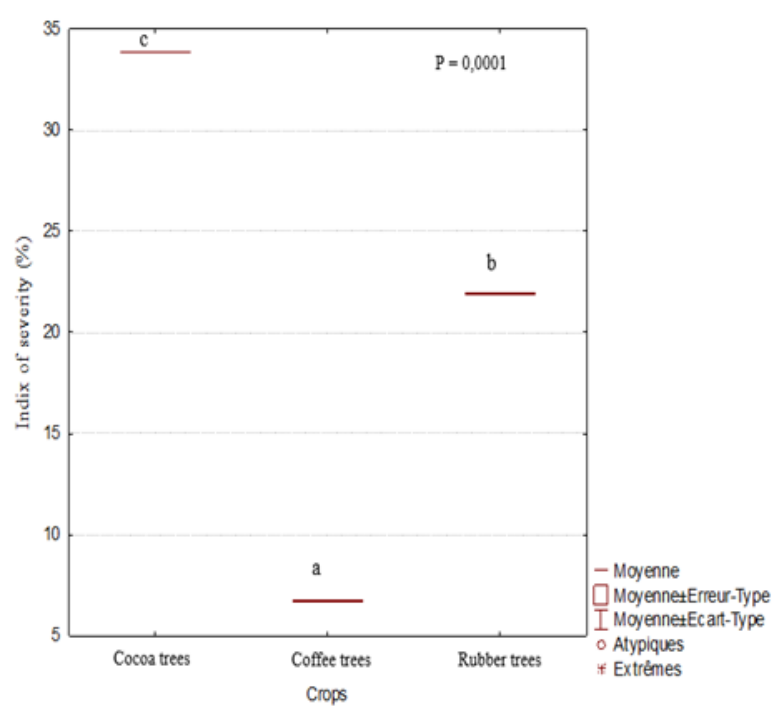

Figure 8 Severity infestation on crops

\subsection{Incidence of crop infestation according to diameter and height classes}

The histograms of the incidences of Loranthaceae infestation on crops show that the incidence values fluctuate according to the diameter classes. Individuals of the diameter classes $(5-10 \mathrm{~cm})$ of cocoa and coffee trees, and of the diameter classes $(10-15 \mathrm{~cm})$ and (>20) of rubber trees are more attacked (fig. 9). The low incidence of infestation is recorded in the diameter classes $(15-20 \mathrm{~cm})$ of cocoa trees and the classes $(0-5 \mathrm{~cm})$ of coffee and rubber trees, respectively.

Regarding the height classes of crops, the values of infestation incidences assessed change from one height class to another (fig. 10). The height class (4-8 $\mathrm{m}$ ) at the level of cocoa and coffee trees, and that of (8-12 $\mathrm{m}$ ) of rubber trees are more attacked. The parasite infestation incidence values obtained on crops increase on the one hand according to the diameter classes and on the other part according to the plant height classes of the parasitized crops. 


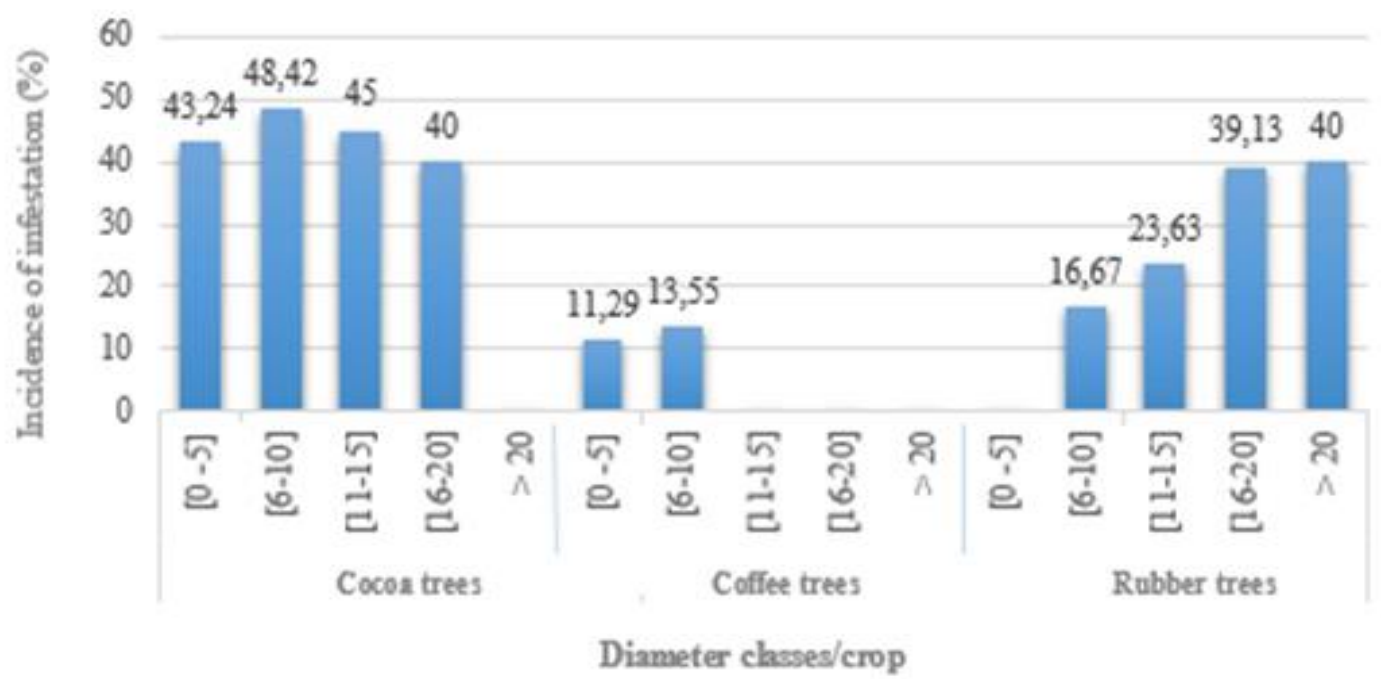

Figure 9 Incidence of infestation according to crop diameter classes

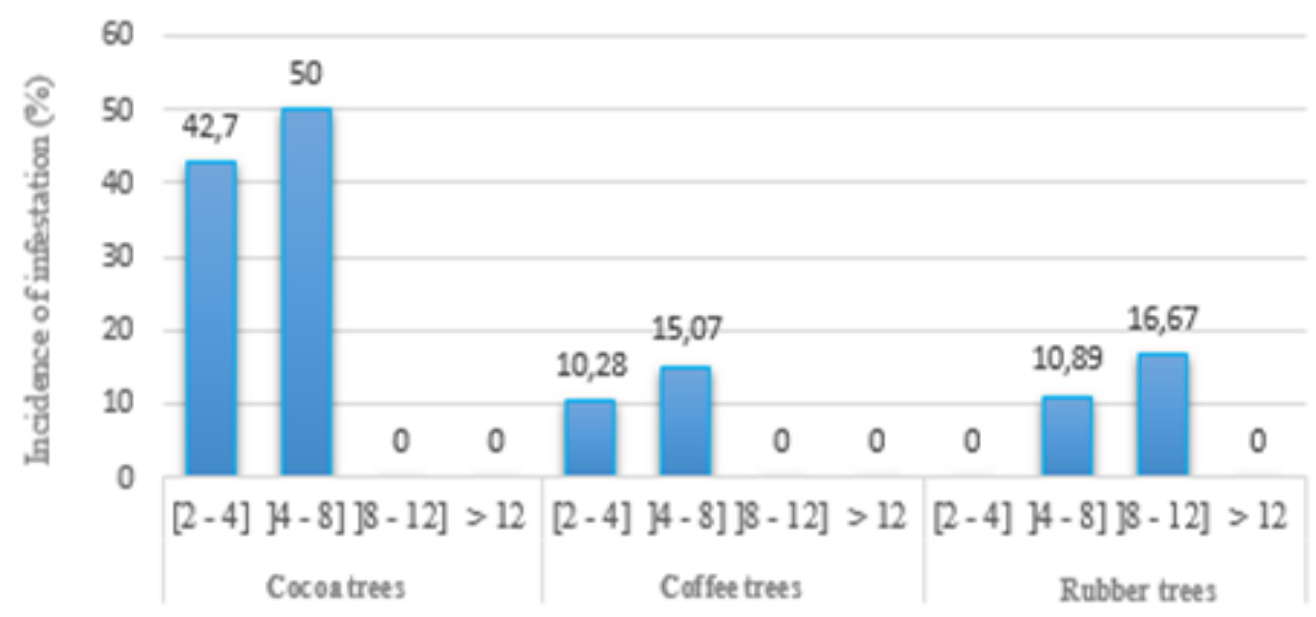

Height dasses/crop

Figure 10 Incidence of infestation according to crop height classes

\section{Discussion}

The study made it possible to inventory 3 species of Loranthaceae in cocoa trees, coffee trees and rubber trees in rural areas of the periphery of the Jean Lorougnon Guédé University. They are: Globimetula. dinklagei subsp. assiana, Phragmenthera capitata var. capitata and Tapinanthus bangwensis. This result differs from that of Soro [21] who inventoried 5 species in Oumé, Gagnoa and Soubré, in the Central West and in the South West of Côte d'Ivoire. Two of these same species (P. capitata and T. bangwensis) have been reported by Amon [9] in agroecosystems in Sud-Comoé, in the South-East of the country. This confirms their ubiquitous character and especially their large distribution in subsaharan Africa underlined by Dibong et al. [23] and Boussim [8], in particular in Côte d'Ivoire by Amon [9]. T. bangwensis is the most abundant parasite on cocoa trees and coffee trees. The predominance of this parasite on the crops in rural areas of the periphery of the University Jean Lorougnon Guédé is not a particularity for this species. Indeed, according to Wood [10], T. bangwensis is one of the cosmopolitan species of the Loranthaceae of the cocoa tree in Africa.

Forty-one (41) host species of Loranthaceae belonging to 34 genera and 21 botanical families were inventoried in cultures of rural areas of the periphery of the Lorougnon Guédé University. This significant diversity of the host species recorded confirms the polyphagous character of Loranthaceae on other plants and in particular of the genus Tapinanthus in sub-saharan Africa reported by Houenon et al. [24] in Benin and Amon [7] in Côte d'Ivoire. The most 
prolific family in terms of host species is that of Fabaceae with 8 taxa (either 19.51\%), followed by Malvaceae with 4 species (9.75\%), Apocynaceae, Euphorbiacae, Moraceae and Rutaceae with each 3 distinct taxa (either. 7.31\%). These results sustain those of Houenon et al. [24] in Benin, Soro [24] and Amon [7, 9]" in Côte d'Ivoire who underlined the significant attack of Fabaceae, Apocynaceae and Rutaceae by Loranthaceae.

Among these hosts, some crop associated species recorded high incidence values. These are Citrus limon (100\%), Cola nitida (80\%), Annona muricata (75\%), Persea americana (54.55\%), Citrus sinensis (40.60\%) and Psidium guajava (30\%). These results confirm the work of Cleck [25] obtained on Cola nitida in Ghana, Dibong et al. [23] on Persea americana in Cameroon and Houenon et al. [24] on Citrus sinensis in Benin. The incidence of Loranthaceae on cocoa trees in rural areas of the periphery of the University Jean Lorougnon Guédé is of the order of $42.86 \pm 7.02 \%$. This incidence value is clearly higher than the $26.90 \%$ obtained by Soro [21] in Oumé. This difference could be explained by the level of maintenance of the sampled plantations.

The Loranthaceae infestation severity index on cocoa trees $(33.99 \pm 7.10 \%)$ is higher than on rubber trees $(21.92 \pm 3.11 \%)$ and coffee trees $(6.72 \pm 1,55 \%)$. These results differ from those of Amon et al. [5] who filed high severity indices on rubber trees than on cocoa trees and coffee trees in the Sud-Comoé region, in the South-East of the Côte d'Ivoire. The differences obtained are linked to the age of the farms and the lack of maintenance.

The incidences of Loranthceae infestation on the main crops (cocoa, coffee and rubber trees) in rural areas of the periphery of the Jean Lorougnon Guédé University vary numerically according to the diameter classes. The incidence values of the diameter classes $(0-5 \mathrm{~cm})$ and $(5-10 \mathrm{~cm})$ of cocoa and coffee trees differ from those of other diameter classes. With regard to the vertical structure of the crop plants, the high incidence values according to the classes of (2-4 $\mathrm{m})$ and (4-8 $\mathrm{m})$ on the one hand in cocoa and coffee trees and on the other hand starts with rubber trees from classes (8-12 m) and over. These results confirm the work of Soro [21] in Côte d'Ivoire and Ondoua et al. [26] in Cameroon.

\section{Conclusion}

The results obtained show that the main types of crops (cocoa, coffee and rubber trees) in rural areas of the periphery of the University Jean Lorougnon Guédé are variously parasitized by three species of Loranthaceae: G. dinklagei subsp. assiana, Phragmenthera capitata var. capitata and Tapinanthus bangwensis. Among these species, Tapinanthus bangwensis is more abundant on cocoa and coffee trees, and P. capitata var. capitata predominantly on rubber trees. A total, of 41 host species were inventoried. The parasitic sensitivity of parasites varies from one parasite species to another. The families most attacked in terms of host species are the Fabaceae and Malvaceae families. Albizia has been identified as the genus with the strongest attack of Loranthaceae. The results indicated a significant difference between the incidences of infestation, the crop severity index as a function of DBH. The incidence and severity index of infestation of Loranthaceae on cocoa, rubber and coffee trees in rural areas of the periphery of the University Jean Lorougnon Guédé taken together are respectively of the order of $24.93 \pm 17.20 \%$ and $20.88 \pm 12.47 \%$. The parasitism of Loranthaceae varies according to the main cultures.

\section{Compliance with ethical standards}

\section{Acknowledgments}

Peasants and authorities from Jean Lorougon Guédé University in Daloa, Côte d'Ivoire.

\section{Disclosure of conflict of interest}

The authors declare no conflict of interest.

\section{Author's contributions}

In the present study, ADEA and SEAH ensured the development of the research protocol, the collection, the data processing and the wording of manuscript. KVA supervised and proofread the differing versions and improved the scientific quality of the manuscript. 


\section{References}

[1] FAO. (2014). Le Travail De La Fao Dans le Domaine de l'Agriculture Familiale, 36.

[2] Esso LJ. (2009). Dynamique des recettes du café et du cacao en Côte d'Ivoire. Politique Économique et Développement. Cellule d'Analyse de Politiques Economiques du CIRES, 18.

[3] MAAF. (2012). Les politiques agricoles à travers le monde. Quelques exemples: Côte d'Ivoire, 6.

[4] Assiri AA, Yoro GR, Deheuvels O, Kebe BI, Keli ZJ, Adiko A and Assa A. (2009). Les caractéristiques agronomiques des vergers de cacaoyer (Theobroma cacao L.), en Côte d'Ivoire, 2(1), 55-66.

[5] Amon ADE, Koulibaly A, Dro B and Soro D. (2017). Parasitisme des Loranthaceae dans les agroécosystèmes à base de cacaoyers, de caféiers et d'hévéas dans la Région du Sud-Comoé, (Côte d'Ivoire). Revue de l'Environnement et de la Biodiversité - PASRES, 2(1), 03-14.

[6] Traoré D, Da KP and Soro D. (2003). Lutte contre les plantes vasculaires parasites du karité, dans le Nord de la Côte d'Ivoire. Cas du parc naturel à karité de Tengrela. Université de Cocody, U.F.R. Biosciences, Laboratoire de Botanique. Rapport de PEP/A.I.S.A. CI, 116.

[7] Amon ADE. (2006). Les plantes vasculaires parasites de la famille des Loranthacée rencontrées dans le Département de Grand-Bassam, au Sud de la Côte d'Ivoire. Mémoire de D.E.A. de Botanique, Université de Cocody, U.F.R. Biosciences. Abidjan, Côte d'Ivoire, 57.

[8] Boussim IJ. (2002). Les phanérogames parasites du Burkina Faso: inventaire, taxonomie, écologie et quelques aspects de leur biologie. Cas particulier des Loranthaceae parasites du karité. Thèse de Doctorat d'Etat ès Sciences Naturelles, FA.S.T., Université de Ouagadougou, 285.

[9] Amon ADE. (2014). Les Loranthaceae (gui) hémiparasites vasculaires des arbres et arbustes des agroécosystèmes de la région du Sud-Comoé, en zone de forêt dense sempervirente de la Côte d'Ivoire. Mémoire de Thèse de l’Université Félix Houphouët- Boigny option Agroforesterie, 213.

[10] Wood. (2008). Cocoa, Tropical agriculture séries, John Wiley \& Sons, IBSN 047069842X, 9780470698426, 620.

[11] Soro K, Gnahoua GM and Traoré D. (2009). Parasitisme des Loranthaceae dans les plantations de Légumineuses arborescentes en zone forestière de la Côte d'Ivoire. Agronomie Africaine, 21(1), 59-69.

[12] Mrankpa AS. (2018). Diversité des Loranthaceae (guis) et des plantes hôtes du site de l'Université Jean Lorougnon Guédé, Côte d'Ivoire. Mémoire de Master de Bioressources et Agronomie, Option: Foresterie, Université Jean Lorougnon Guédé, Daloa, 60.

[13] Guillaumet JL and Adjanohoun E. (1971). La végétation. In: le milieu naturel de la Côte d'Ivoire. Mémoire ORSTOM, 50, 157-263.

[14] Hall JB and Swaine MD. (1981). Distribution and ecology of vascular plants in a rain forest vegetation in Ghana. Geobotany, 383.

[15] Mohamed SZ, Abbasher AA and Eldur BZ. (2013). Incidence and severity of the mistletoe Tapinanthus globiferus on guava and lime and its mechanical control in the Gezira State, Sudan. Journal of Agricultural and Veterinary Science, (4)1, 44-51.

[16] Hoffmann G. (1994). Contribution à l'étude des Phanérogames parasites du BurkinaFaso et du Mali: quelques aspects de leur biologie et techniques de lutte. Thèse de doctorat de l'Université de Droit, d'Economie et des Sciences d'Aix Marseille III, 65.

[17] Asare-Bediako E, Addo-Quaye AA, Tetteh JP, Buah JN, Van Der Puije GC and Acheampong RA. (2013). Prevalence of Mistletoe On Citrus Trees In The Abura-Asebu-Kwamankese District Of The Central Region Of Ghana. International Journal of Scientific \& Technology Research, 7(2), 122-127.

[18] Aké-Assi L. (2002). Flore de Côte d'Ivoire 2, catalogue systématique, biogéographie et écologie. Conservatoire et Jardin Botaniques, Genève, 401.

[19] Bongers F, Poorter L and Hawthorne WD. (2005). The forests of Upper Guinea: gradients in large species composition. In: Poorter L., Bongers F., Kouamé F. N., Hawthorne W. D. (éd.). Biodiversity of West African Forest. An ecological atlas of woody plants species. Wallingford, Royaume-Uni, CABI Publishing, 41-5.

[20] Ballé S and Hallé N. (1961). Les Loranthaceae de la Côte d'Ivoire. Adansonia, nouvelle série, tome, 1, $210-265$. 
[21] Soro K. (2010). Les Loranthaceae ou guis, plantes vasculaires parasites des arbres et arbustes cultivés ou non, dans l'ouest de la Côte d'ivoire : cas des départements d'Oumé, de Gagnoa et de Soubré. Thèse Unique d'Écologie Végétale, option Agroforesterie, Université de Cocody, Abidjan, 189.

[22] Dagnelie P. (1980). Théorie et méthodes statistiques, application agronomique. Vol. 2. Gembloux, Belgique: Presses agronomiques de Gembloux.

[23] Dibong S Engone Obiang NL, Din N, Priso RJ, Taffouo VD, Fankem H and Amougou A. (2009). Niveau d'infestation des arbres fruitiers des groupements végétaux par Phragmanthera capitata (Sprengel) S. Balle (Loranthaceae) dans la région littorale du Cameroun, Int. J. Biol. Chem. Sci, 3(2), 347-354.

[24] Houenon GJ, Yedomonhan H, Adomou AC, Tossou GM, Akoegninou A and Traoré. (2012). Diversité Spécifique des Loranthaceae Parasites des Agrumes et Leurs Impacts Sur la Production Agrumicole au Sud du Bénin. European Journal of Scientific Research, 527-538.

[25] Clerk G. (1978). Tapinanthus bangwensis in a Cola plantation in Ghana. PANS, 24, 57-62.

[26] Ondoua JM, Dibong SD, Taffouo VD and Ngotta BJB. (2015). Parasitisme des champs semenciers de cacaoyers par les Loranthaceae dans la localité de Nkoemvone (sud Cameroun). Journal of Applied Biosciences, 85: 7794-7803. 